\title{
Antioxidant Activity, Quality Parameters and Grain Characteristics of Rice Varieties of Afghanistan
}

\author{
Ramin Rayee ${ }^{1,2}$, Tran Dang Xuan ${ }^{1,{ }^{*}}$, Kifayatullah Kakar $^{1}$ \\ and M. Ismael Haqani ${ }^{1}$ \\ ${ }^{1}$ Graduate School for International Development and Cooperation (IDEC), Hiroshima University, \\ Higashi-Hiroshima, Hiroshima 739-8529, Japan \\ ${ }^{2}$ Agronomy Department, Faculty of Agriculture, Takhar University, Takhar, Afghanistan \\ "tdxuan@hiroshima-u.ac.jp; Tel./Fax: +81-82-424-6927
}

Keywords: antioxidant activity, grain characteristics, grain quality contents.

\begin{abstract}
Rice is one of the main source of food calories in the world, especially in Asia where the people eat it more than any other food. The goal of this study was to evaluate the antioxidant activity, grain traits and quality contents in Afghanistan's selected rice varieties. The antioxidant capacity was measured using DPPH (1,1-diphenyl-2-picrylhydrazyl) and Reducing Power methods. Grain length, grain width and grain thickness were in the range of 5.4-7.6, 1.7-3.2, and 1.5-2.2 mm respectively. Selah Zoodras, Taram Irani and Attai-1 had the longest grain length whereas Loke was associated with high width and thickness among the varieties. Protein, amylose and lipid content varied from 6.5-9.9, 20.3-23.5, and 10-18\% respectively. Barah Kunduz showed the highest protein and lipid content while Selah zoodras was associated the highest amylose content. The selected rice varieties possessed moderate antioxidant activity and their physiochemical properties were not correlated with antioxidant capacity. Results of this study provided useful information on the selection and production of rice varieties with high nutritional and pharmaceutical values in Afghanistan.
\end{abstract}

\section{Introduction}

Rice (Oryza sativa L.) is the most important food crop in the world which is providing the primary source of calories for the $50 \%$ of the human population [1]. It is a significant stable food in Asia where about $90 \%$ of the world's rice is produced and consumed [2]. Rice is the major stable food after wheat in Afghanistan and is cultivated widely in the north eastern, and south parts respectively [3]. Baghlan, Kunduz, Takhar provinces in the northeast and Nangarhar province in the south are considered to be the grain stock of rice in Afghanistan and playing a vital role for food security in the national level [4]. The rice yield production has a nonlinear relation with cultivation area in Afghanistan. Based on the report by ICARDA [5], the rice production has been increased from $3.22 \mathrm{t} / \mathrm{ha}$ in 2008 to $3.50 \mathrm{t} / \mathrm{h}$ in 2010 . In contrary, the cultivation area has been decreased due to climate change impact [6].

Grain as the main product of rice and the source of nutritional elements, plays a crucial role in defending the body from the oxidative damages. Free radicals can cause oxidative damage to biomolecules such DNA, proteins and lipids and leads to chronic disease. Therefore, the consumption of whole grain can be a mechanism of prevention these diseases [7, 8]. Rice grain contains a large portion of antioxidants which are ingested daily by the people and many compounds such as phenolics and anthocyanin are found in this cereal [9] and its antioxidation is mostly related to phenolic compounds [10]. The daily consumption of the secondary metabolites as source of antioxidants in the diets will inhibit the development of chronic diseases and reduce the impact of oxidative stress [11]. It is reported that black rice bran has higher antioxidant activity than white rice bran. It was observed that rice potential health benefits seem to be related to its pericarp [12]. Some compounds mainly phenolics and anthocyanin have been studied and detected under germinated and normal conditions [9]. Alongside the rice yield and production, its quality has a crucial role in the adoption of new varieties. Grain quality properties is a dominant factor in economic returns for farmers and it really 
dictate market value in Afghanistan where the demand for the high-quality rice and its consumption is raising due to population growth. Rice varieties which selected for this research have only been evaluated by their yield production, and still there is lack of investigation for characterization of their genotypic variation. Therefore, the objective of this research was to evaluate the antioxidant activity, grain quality content and grain traits of Afghanistan selected rice varieties. These findings could help the breeders and commercial rice growers to choose high-quality varieties for the future rice production in Afghanistan.

\section{Materials and Methods}

\section{Rice materials}

The varieties selected for this research are cultivated widely in Afghanistan. These varieties could be representative of other native rice varieties in Afghanistan. Selah zoodras, Barah Kunduz and Sha Lawangi are famous aromatic rice varieties in Afghanistan. The seeds of 10 rice varieties (Table 1) were collected from the Departments of Agriculture, Irrigation and Livestock (DAILs), Afghanistan. The seeds moisture content was adjusted to $14 \%$ using oven method. The dried seeds stored in air-tight plastic bags in the room temperature. The seeds were dehulled using Automatic Rice Husker Machine (model TR-250, Kett Electric Laboratory, Tokyo, Japan) to measure the quality content, then grounded to pass through a 100-mesh sieve for further analyses.

Table 1. Rice materials description.

\begin{tabular}{|c|c|c|c|}
\hline No & Local Name & Type & Genotype \\
\hline 1 & Bara kunduz & Indica & Variety \\
\hline 2 & Selah zoodras & Indica & Variety \\
\hline 3 & Zerati Garma & Indica & Variety \\
\hline 4 & Surkhah zerati & Indica & Variety \\
\hline 5 & Taram irrani & Indica & Variety \\
\hline 6 & Shah Lawangi & Indica & Variety \\
\hline 7 & Loke & Japonica & Variety \\
\hline 8 & Jalal Abad-14 & Indica & Variety \\
\hline 9 & Shesham bagh-14 & Indica & Variety \\
\hline 10 & Attai-1 & Indica & Variety \\
\hline
\end{tabular}

\section{Quality Contents}

Protein, amylose and lipid contents were measured using quality tester machine PGC Shizuoka Seiki PS-500 machine (version 2-12, Shizuoka Seiki Co., Ltd., Shizuoka, Japan).

\section{Physical Properties}

Grain length, grain width, grain length and width ratio, and grain thickness were measured using a Vernier Caliper. The 1000-grain weight measured in triplicate from one hundred brown grain.

\section{Extraction}

The extraction was followed the method reported by Shao et al. [13]. Briefly, one gram of rice

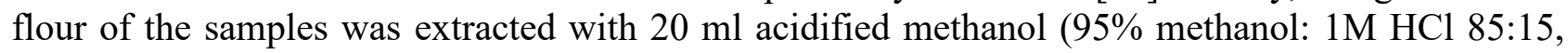


$\mathrm{v} / \mathrm{v})$ twice. The mixture was shaken under room temperature for 4 hours. The mixture was then centrifuged at $15,300 \mathrm{rpm}$ for $10 \mathrm{~min}$ at $4{ }^{\circ} \mathrm{C}$ and the supernatant was collected and combined. The supernatant was evaporated using rotary evaporator (SB-350-EYELA, Tokyo, Japan) at $37{ }^{\circ} \mathrm{C}$ to remove the methanol after adjusting the $\mathrm{pH}$ 1.5-2.0. The precipitates were defatted by hexane three times then extracted with $60 \mathrm{ml}$ of ethyl acetate three times. The ethyl acetate extracts evaporated to dryness by rotary evaporator. The dried extract was dissolved in $50 \%$ methanol for further analysis.

\section{Antioxidant Activity}

\section{Measurement of DPPH Radical Scavenging Activity}

Antioxidant activity was determined following the method described by Elzaawely et al. [14]. A $0.5 \mathrm{ml}$ of the extract was mixed with $0.25 \mathrm{ml}$ of DPPH solution and $0.1 \mathrm{ml}$ of $0.1 \mathrm{M}$ acetate buffer $\mathrm{pH}$ (5.5). The mixture was shaken and kept at room temperature for $30 \mathrm{~min}$ in the dark place. The absorbance was measured at $517 \mathrm{~nm}$ using microplate reader (Thermo Scientific Multiskan GO, Japan). The BHT (dibutyl hydroxytoluene) standard (5-20 ppm) was used as the positive control. The $\mathrm{IC}_{50}$ value was calculated, thus the lower $\mathrm{IC}_{50}$ indicates the higher antioxidant activity. The following formula is used to measure the percentage of DPPH radical scavenging activity.

DPPH Radical Scavenging Activity $(\%)=[($ Acontrol - Asample $) /$ Acontrol $] \times 100$.

In the formula, Acontrol is absorbance of reaction without a sample, Asample is the absorbance of the sample.

\section{Estimation of Reducing Power}

Reducing power was measured following the method reported by Singh [15]. Briefly, $0.1 \mathrm{ml}$ of the extract was added in $2.5 \mathrm{ml}$ potassium ferricyanide $(1 \%)$ and $2.5 \mathrm{ml}$ of phosphate buffer $(0.2 \mathrm{M}$, $\mathrm{pH}$ 6.5). After incubation at $50{ }^{\circ} \mathrm{C}$ for $30 \mathrm{~min}, 2.5 \mathrm{ml}$ of trichloroacetic acid (10\%) was added to the mixture. The mixture was centrifuged at $4000 \mathrm{rpm}$ for $10 \mathrm{~min}$. Then, $2.5 \mathrm{ml}$ of the supernatant was taken out and mixed with $2.5 \mathrm{ml}$ of distilled water and $0.5 \mathrm{ml} \mathrm{FeCl3}(0.1 \%)$ was added. The absorbance was measured at $700 \mathrm{~nm}$ using a microplate reader (Thermo Scientific Multiskan GO, Japan). The BHT standard (5-20 ppm) was used as the positive control. The $\mathrm{IC}_{50}$ value was calculated, thus the lower $\mathrm{IC}_{50}$ indicated the higher antioxidant activity. Reducing power capacity expressed as bellow.

$$
\text { Reducing Power Capacity (\%) = 100- }(\text { Ao-As/Ao } \times 100) \text {, }
$$

where $A o$ is the absorbance without sample, $A s$ is the absorbance of the sample.

\section{Statistical Analysis}

The data were analyzed using Minitab 16.0 (Minitab Inc. State college, PA, USA). Results were presented means \pm standard deviation (SD). Differences among verities were analyzed by one-way ANOVA (Analysis of Variance), followed by Tukey multiple comparison tests. Correlations among the traits were performed using Pearson's Method. Statistical significance was defined at 5\% level.

\section{Results and Discussion}

\section{Physical traits of the samples}

The grain seizes, and other traits differed dramatically among the samples (Table 2, Fig. 1). The grain length ranged from $5.3 \mathrm{~mm}$ to $7.6 \mathrm{~mm}$ while the grain width varied from $1.7 \mathrm{~mm}$ to $3.2 \mathrm{~mm}$. Grain thickness ranged from $1.5 \mathrm{~mm}$ to $2.2 \mathrm{~mm}$, and the 1000 -grain weight was between $16.3 \mathrm{~g}$ to 23.8 g. Selah Zoodras, Taram Irani and Attai-1 had the longest grain length $(7.6 \mathrm{~mm})$ and followed by Zerati Garma, Shalawangi, Bara Kunduz, Jalal Abad-14 and Loke, while Sheshambagh-14 showed the shortest grain length $(5.4 \mathrm{~mm})$ (Table 2). Loke was the plump one with largest grain width $(3.2 \mathrm{~mm})$, thickness $(2.2 \mathrm{~mm})$ and highest 1000 -grain weight $(23.8 \mathrm{~g})$. The shortest grain width was 
recorded at Selah Zoodras and Attai-1 $(1.7 \mathrm{~mm})$. Previous studies reported that proper grain traits are considered by breeders when developing new varieties for release and marketable production [16]. Sheshambagh-14 had the lowest 1000-grain weight among the samples. Grains with long length, low amylose and high protein are preferable for the people in Afghanistan.

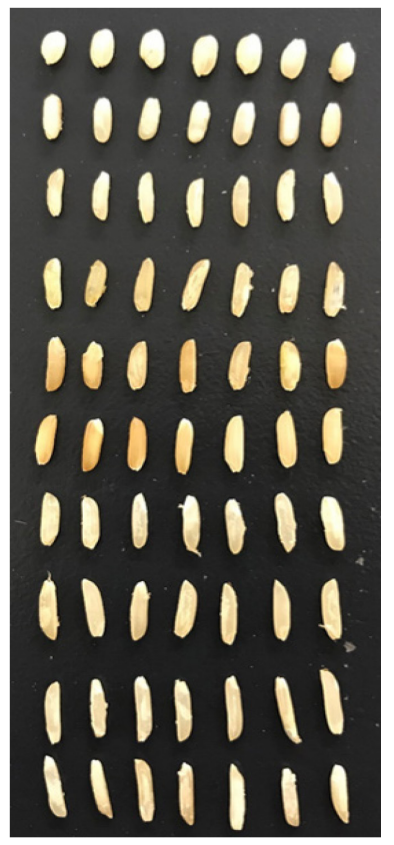

Figure 1. Rice genotypes used in this study arranged according to their lengths.

Table 2. Grain characteristics of the varieties.

\begin{tabular}{|c|c|c|c|c|c|}
\hline Variety & GL & GW & RLW & GT & $\begin{array}{c}\text { 1000-Grain } \\
\text { Weight (g) }\end{array}$ \\
\hline Bara Kunduz & $7.1 \pm 0.5^{\mathrm{abc}}$ & $2.1 \pm 0.2^{\mathrm{bc}}$ & $3.3 \pm 0.4^{\mathrm{b}}$ & $1.7 \pm 0.1^{\mathrm{bcd}}$ & $23.7 \pm 0.4^{\mathrm{a}}$ \\
\hline Selah Zoodras & $7.6 \pm 0.4^{\mathrm{a}}$ & $1.7 \pm 0^{\mathrm{d}}$ & $4.5 \pm 0.3^{\mathrm{a}}$ & $1.5 \pm 0^{\mathrm{ef}}$ & $16.7 \pm 0.1^{\mathrm{ef}}$ \\
\hline Zerati Garma & $7.4 \pm 0.3^{\mathrm{ab}}$ & $2.2 \pm 0.2^{\mathrm{bc}}$ & $3.3 \pm 0.4^{\mathrm{b}}$ & $1.7 \pm 0^{\mathrm{bcd}}$ & $21.8 \pm 0.4^{\mathrm{b}}$ \\
\hline Surkhah Zerati & $6.9 \pm 0.6^{\mathrm{bc}}$ & $2.3 \pm 0.2^{\mathrm{b}}$ & $3.1 \pm 0.2^{\mathrm{b}}$ & $1.8 \pm 0.1^{\mathrm{b}}$ & $21 \pm 0.2^{\mathrm{bc}}$ \\
\hline Taram Irani & $7.6 \pm 0.5^{\mathrm{a}}$ & $2.3 \pm 0.4^{\mathrm{b}}$ & $3.4 \pm 0.6^{\mathrm{b}}$ & $1.7 \pm 0.1^{\mathrm{bcd}}$ & $20.3 \pm 0.2^{\mathrm{c}}$ \\
\hline Shah Lawangi & $7.2 \pm 0.5^{\mathrm{abc}}$ & $2.3 \pm 0.2^{\mathrm{b}}$ & $3.2 \pm 0.4^{\mathrm{b}}$ & $1.8 \pm 0.1^{\mathrm{bc}}$ & $20.7 \pm 0.1^{\mathrm{c}}$ \\
\hline Loke & $5.3 \pm 0.3^{\mathrm{d}}$ & $3.2 \pm 0.4^{\mathrm{a}}$ & $1.7 \pm 0.2^{\mathrm{d}}$ & $2.2 \pm 0.10^{8 \mathrm{a}}$ & $23.8 \pm 0.3^{\mathrm{a}}$ \\
\hline Jalal Abad-14 & $6.7 \pm 0.4^{\mathrm{c}}$ & $2 \pm 0.3^{\mathrm{c}}$ & $3.3 \pm 0.4^{\mathrm{b}}$ & $1.7 \pm 0.1^{\mathrm{cd}}$ & $17.7 \pm 0.3^{\mathrm{d}}$ \\
\hline Sheshambagh-14 & $5.4 \pm 0.3^{\mathrm{d}}$ & $2.2 \pm 0.1^{\mathrm{bc}}$ & $2.4 \pm 0.1^{\mathrm{c}}$ & $1.6 \pm 0.1^{\mathrm{de}}$ & $16.3 \pm 0.2^{\mathrm{f}}$ \\
\hline Attai-1 & $7.6 \pm 0.5^{\mathrm{a}}$ & $1.7 \pm 0.1^{\mathrm{d}}$ & $4.4 \pm 0.3^{\mathrm{a}}$ & $1.5 \pm 0.1^{\mathrm{f}}$ & $17.4 \pm 0.5^{\mathrm{de}}$ \\
\hline ANOVA & \multicolumn{5}{|c}{} \\
\hline Variety & $*$ & $*$ & $*$ & $*$ & $*$ \\
\hline
\end{tabular}

GL: Grain Length, GW: Grain Width, RLW: Ratio of Grain, Lenght, GT: Grain Thickness. Means with same letter in a column are not significantly different at $5 \%$ level. * indicates significant differences at $(\mathrm{p}<0.05)$. 


\section{Grain Quality Content}

Grain quality contents are shown in Table 3. The result showed that there is a wide difference of quality contents except for amylose content among the varieties. In this study protein content ranged from $6.5 \%$ to $9.9 \%$, amylose content varied from $20.3 \%$ to $23.5 \%$ and lipid content $10 \%$ to $18 \%$. Jing et al. [17] reported that amylose content varied from $8 \%$ to $16 \%$ between places and from $5 \%$ to $22 \%$ among varieties. Protein content is different among varieties, but it is raised and accumulated in the grain due to fertilizer application [18]. Bara Kunduz associated with the highest significant protein content $(9.9 \%)$ followed by, Shah Lawangi, Sheshambagh-14, Tarram irrani, Surkha Zerati, Loke and Zerati Garma (9.2, 8.9, 8.8, 8.3, 7.8, and 6.5\%) respectively. Protein content accumulation is remarkably affected by many factors, such environment, genetic interaction and mailing process [19]. All the values of the protein content in this study were lower than $10 \%$. Based on the previous studies and increase to the protein content higher than $10 \%$ will decrease lysin which affects negatively the rice digestibility [20]. Attai-1 contained the highest amylose content (23.5\%) while Selah Zoodras had the lowest (20.3\%). Among the varieties, Surkhah Zerati associated with the highest lipid content (18\%), whereas the lipid contends declined to $10 \%$ at Bara Kunduz.

Table 3. Grain quality contents of the varieties.

\begin{tabular}{|l|c|c|c|}
\hline \multicolumn{1}{|c|}{ Variety } & PC (\%) & AC (\%) & LP (\%) \\
\hline Bara Kunduz & $9.9 \pm 0.1^{\mathrm{a}}$ & $20.9 \pm 0.1^{\mathrm{ab}}$ & $10 \pm 0^{\mathrm{f}}$ \\
\hline Selah Zoodras & $7.5 \pm 0.15^{\mathrm{ef}}$ & $20.3 \pm 5.7^{\mathrm{b}}$ & $11 \pm 0^{\mathrm{e}}$ \\
\hline Zerati Garma & $6.5 \pm 0.1^{\mathrm{g}}$ & $22.8 \pm 0.1^{\mathrm{ab}}$ & $12.7 \pm 0.6^{\mathrm{d}}$ \\
\hline Surkhah Zerati & $8.3 \pm 0.2^{\mathrm{cd}}$ & $22.8 \pm 0.1^{\mathrm{ab}}$ & $18 \pm 0^{\mathrm{a}}$ \\
\hline Taram Irrani & $8.8 \pm 0.12^{\mathrm{bc}}$ & $23.1 \pm 0.1^{\mathrm{ab}}$ & $13.7 \pm 0.6^{\mathrm{c}}$ \\
\hline Shah Lawangi & $9.2 \pm 0.12^{\mathrm{b}}$ & $22.7 \pm 0.1^{\mathrm{ab}}$ & $16 \pm 0^{\mathrm{b}}$ \\
\hline Loke & $7.8 \pm 0.2 \mathrm{~d}^{\mathrm{e}}$ & $22 \pm 0.6^{\mathrm{ab}}$ & $13 \pm 0^{\mathrm{cd}}$ \\
\hline Jalal Abad-14 & $7.1 \pm 0.06^{\mathrm{f}}$ & $22.1 \pm 0.2^{\mathrm{ab}}$ & $11 \pm 0^{\mathrm{e}}$ \\
\hline Sheshambagh-14 & $8.9 \pm 0.2^{\mathrm{b}}$ & $22.5 \pm 0.1^{\mathrm{ab}}$ & $10 \pm 0^{\mathrm{f}}$ \\
\hline Attai-1 & $7.8 \pm 0.15^{\mathrm{de}}$ & $23.5 \pm 0.3^{\mathrm{a}}$ & $11 \pm 0^{\mathrm{e}}$ \\
\hline ANOVA & & \multicolumn{3}{|c|}{$\mathrm{NS}$} & $*$ \\
\hline \multicolumn{1}{|c|}{ Variety } & $*$ & \multicolumn{2}{|c|}{} \\
\hline
\end{tabular}

PC: Protein Content; AC: Amylose Content; LP: Lipid Content. Means with same letter in a column are not significantly different at $5 \%$ level. $*$ indicates significant differences at $(\mathrm{p}<0.05)$ and NS indicates non-significant.

The relationship between $\mathrm{AC}$ and other grain properties is shown in Fig. 2. The results indicate that there is a nonlinear relation between $\mathrm{AC}$ and PC, LP, GL and GW $\left(\mathrm{R}^{2}=0.02, \mathrm{R}^{2}=0.16, \mathrm{R}^{2}=\right.$ 0.00 , and $\mathrm{R}^{2}=0.01$ ) respectively. 

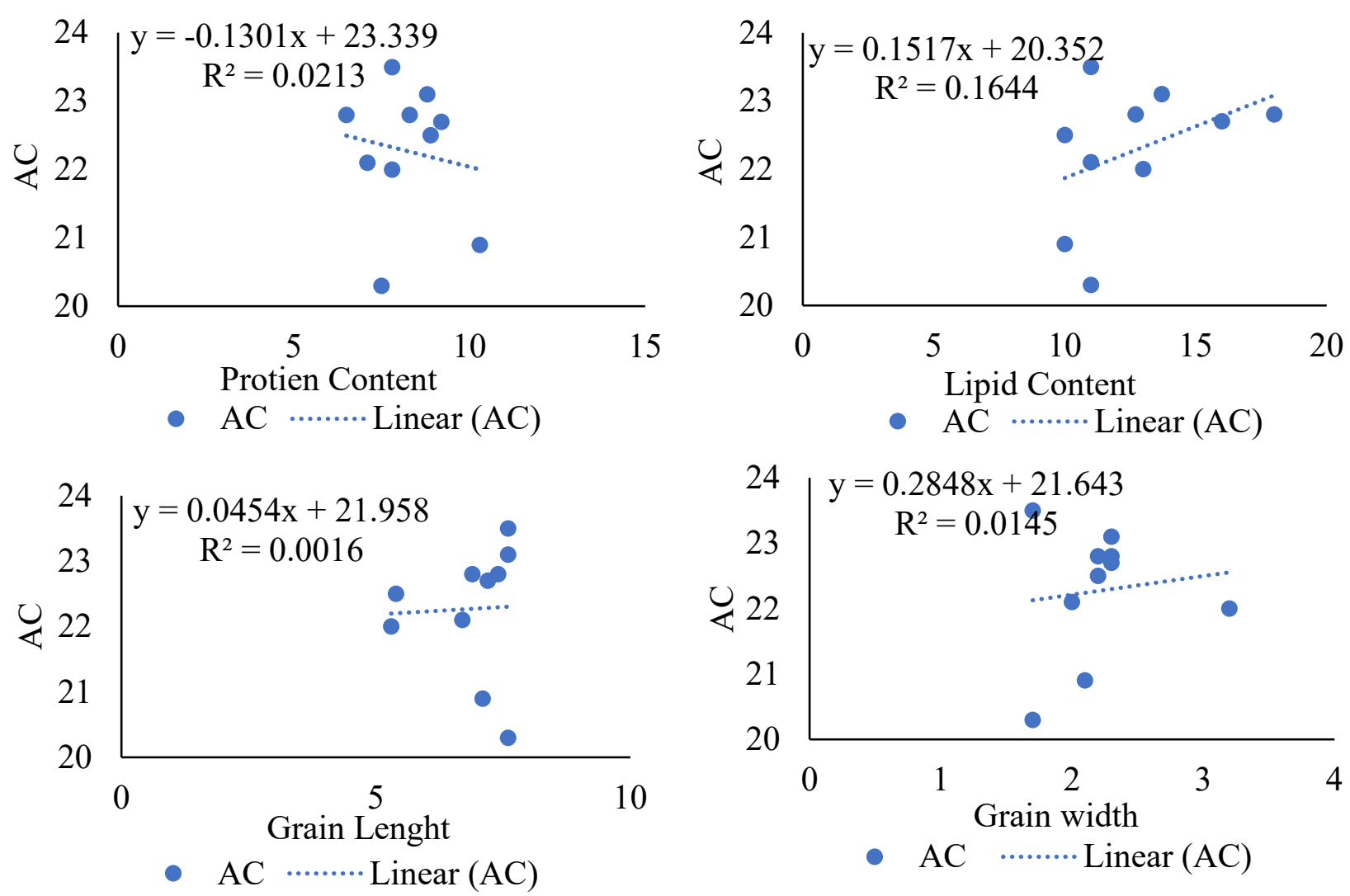

Figure 2. The relation of AC with, protein, content, lipid content, grain length and grain width.

\section{Antioxidant Activity (AA)}

Table 4 showed the result of the samples antioxidant activity. The varieties revealed a highly significant variation $(p<0.05)$ for antioxidant activity in both DDPH and Reducing assays. The $\mathrm{IC}_{50}$ values for DPPH assay ranged from $3.1 \mathrm{mg} / 1$ (Shah Lawangi) to $8.3 \mathrm{mg} / \mathrm{ml}$ (Selah Zoodras). These findings are consistent with $\mathrm{IC}_{50}$ values $(6.01-14.47 \mathrm{mg} / \mathrm{ml})$ of DPHH assay in Bangaladish rice varieties which reported by Dutta et al. [21]. The grain extract of Shah Lawange in DPPH assay expressed the highest scavenging activity with the value of $3.1 \mathrm{mg} / \mathrm{ml}$ followed by Loke, Surkha Zerati, Sheshambagh-14, Attai-1 $(4.29,5.66,6.18$ and $7 \mathrm{mg} / \mathrm{ml})$ respectively. All the $\mathrm{IC}_{50}$ values of the sample extracts were higher than BHT standard of DDPH $(2.9 \mathrm{mg} / \mathrm{ml})$ and reducing power $(11.14 \mathrm{mg} / \mathrm{ml})$ not shown in Table 4 . Antioxidant activity in the reducing power assay was lower than DPPH assay (Table 4). The highest $\mathrm{IC}_{50}$ value for reducing power observed in Jalal Abad-14 $(29.28 \mathrm{mg} / \mathrm{ml})$, whilst the lowest was revealed in Sha Lawangi $(10.06 \mathrm{mg} / \mathrm{ml})$. The current finding indicates that genetic variation, soil types and environmental conditions may have contributed to the antioxidant capacity of varieties and the data suggests that the varieties have moderate antioxidant activity $[22,23]$. 
Table 4. Grain antioxidant activity in term of $\mathrm{IC}_{50}$.

\begin{tabular}{|c|c|c|}
\hline Variety & DPPH (IC $\mathbf{5 0} \mathbf{~ m g / m l})$ & Reducing Power $\left(\right.$ IC $\left._{\mathbf{5 0}} \mathbf{~ m g} / \mathbf{m l}\right)$ \\
\hline Bara Kunduz & $4.41 \pm 0.83^{\mathrm{bcd}}$ & $13.02 \pm 0.74^{\mathrm{bc}}$ \\
\hline Selah Zoodras & $8.3 \pm 0.72^{\mathrm{a}}$ & $12.35 \pm 2.48^{\mathrm{bc}}$ \\
\hline Zerati Garma & $4.95 \pm 0.77^{\mathrm{bcd}}$ & $15.36 \pm 3.78^{\mathrm{abc}}$ \\
\hline Surkhah Zerati & $5.66 \pm 0.6^{\mathrm{abcd}}$ & $11.72 \pm 1.45^{\mathrm{bc}}$ \\
\hline Taram Irrani & $3.74 \pm 0.46^{\mathrm{cd}}$ & $11.56 \pm 0.43^{\mathrm{bc}}$ \\
\hline Shah Lawangi & $3.1 \pm 0.3^{\mathrm{d}}$ & $10.06 \pm 0.87^{\mathrm{c}}$ \\
\hline Loke & $4.29 \pm 0.01^{\mathrm{bcd}}$ & $29.28 \pm 11.12^{\mathrm{a}}$ \\
\hline Jalal Abad-14 & $3.49 \pm 0.12^{\mathrm{cd}}$ & $22.46 \pm 9.46^{\mathrm{abc}}$ \\
\hline Sheshambagh-14 & $6.18 \pm 1.75^{\mathrm{abc}}$ & $25.98 \pm 6.44^{\mathrm{ab}}$ \\
\hline Attai-1 & $7 \pm 2.31^{\mathrm{ab}}$ & $*$ \\
\hline ANOVA & & \\
\hline Variety & $*$ & \\
\hline
\end{tabular}

Means with same letter in a column are not significantly different at 5\% level. * indicates significant differences at $(\mathrm{p}<0.05)$.

The relation of AA and other grain properties is shown in Fig. 3. The results showed that there is a nonlinear relation between $\mathrm{AA}$ and $\mathrm{PC}, \mathrm{AC}, \mathrm{GL}, \mathrm{LC}$ and $\mathrm{GW}\left(\mathrm{R}^{2}=0.069, \mathrm{R}^{2}=0.007, \mathrm{R}^{2}=\right.$ $0.0097, \mathrm{R}=0.061$ and $\mathrm{R}^{2}=0.027$ ) respectively. Based on these findings AA correlation could not be considered in the breeding or production of rice varieties.
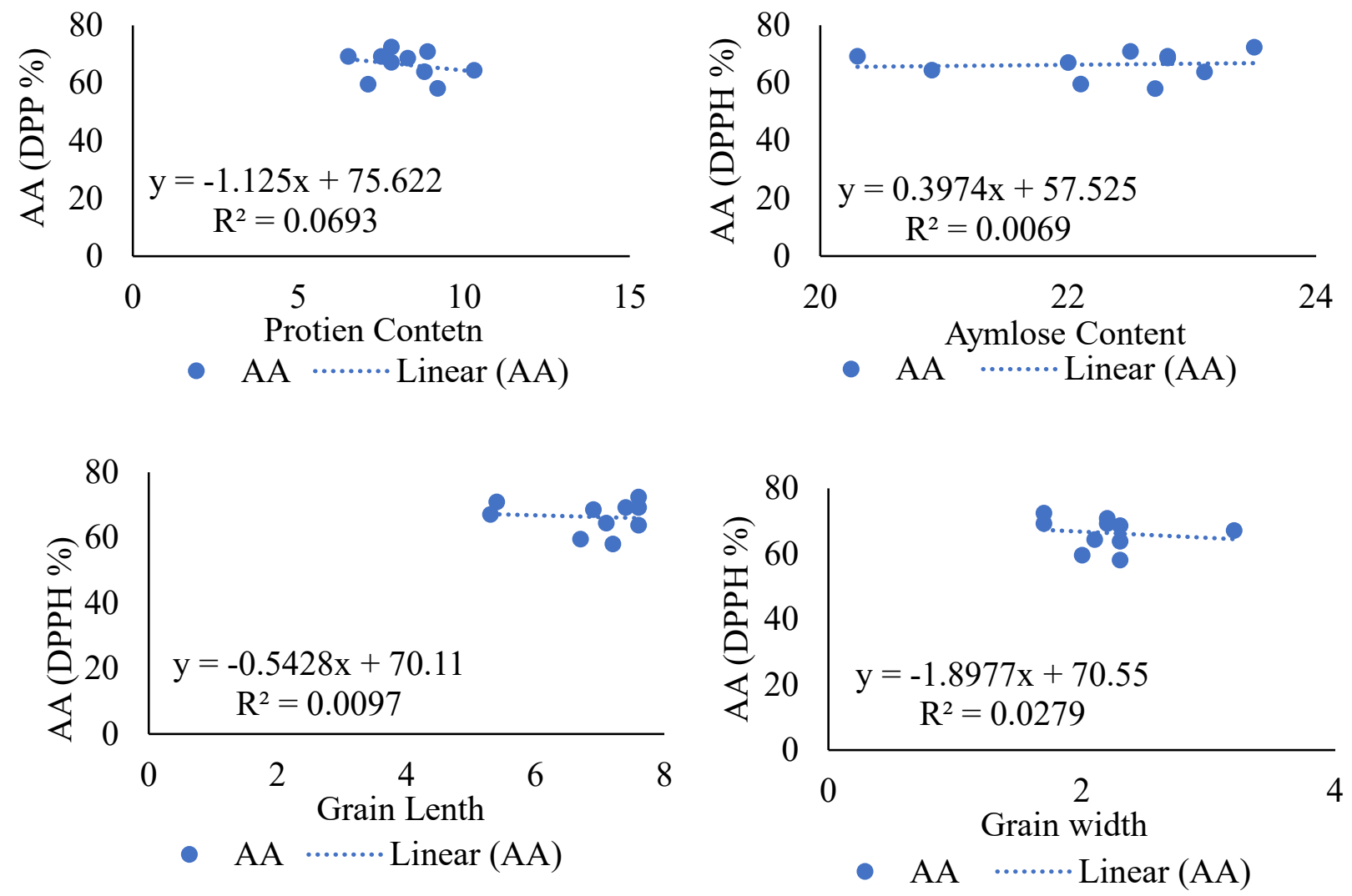


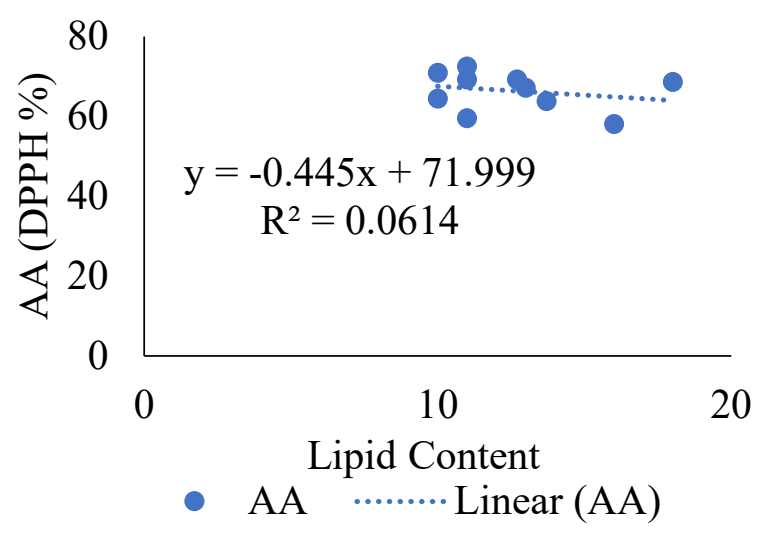

Figure 3. The relationship of AA with, protein content, amylose content, grain length grain width, and lipid content.

\section{Inter correlation of grain physiochemical characteristics}

The correlation coefficient of antioxidant activity, quality content and grain traits are presented in Table 5. The indicates that grain length showed a significant positive correlation with grain lengthwidth ratio $(r=0.87, p<0.05)$ Table 5 , while it had a significant negative association with grain width $(r=-0.67, p<0.05)$. Grain width correlated negatively significant with grain length-width ratio $(r=-0.89, p<0.05)$. The data showed that there is no significant correlation between quality content and other grain traits.

Table 5. Correlation coefficients of grain physical and biochemical traits.

\begin{tabular}{|c|l|l|l|l|l|l|l|}
\hline & AA & GL & GW & LWR & AC & PC & LC \\
\hline AA & 1 & & & & & & \\
\hline GL & $-0.10 \mathrm{~ns}$ & 1 & & & & & \\
\hline GW & $-0.17 \mathrm{~ns}$ & $-0.67 *$ & 1 & & & & \\
\hline LWR & $0.14 \mathrm{~ns}$ & $0.87 *$ & $-0.89 *$ & 1 & & & \\
\hline AC & $0.08 \mathrm{~ns}$ & $0.04 \mathrm{~ns}$ & $0.12 \mathrm{~ns}$ & $-0.12 \mathrm{~ns}$ & 1 & & \\
\hline PC & $-0.26 \mathrm{~ns}$ & $-0.08 \mathrm{~ns}$ & $0.08 \mathrm{~ns}$ & $-0.16 \mathrm{~ns}$ & $-0.15 \mathrm{~ns}$ & 1 & \\
\hline LC & $-0.25 \mathrm{~ns}$ & $0.13 \mathrm{~ns}$ & $0.36 \mathrm{~ns}$ & $-0.17 \mathrm{~ns}$ & $0.41 \mathrm{~ns}$ & $0.02 \mathrm{~ns}$ & 1 \\
\hline
\end{tabular}

* indicates significant, ns non-significant correlation at 0.05 level; AA: antioxidant activity; GL: grain length; GW: grain width; LWR: ratio of length to width; AC: amylose content; PC: protein content; LC: lipid content

\section{Conclusion}

The results of this study imply that there was a high variation for the grain traits, quality contents and antioxidant activity. The varieties showed moderate protein content, but the amylose values were high in all varieties. These selected varieties possessed a moderate antioxidant activity. The demand for rice with high quality and yield is raising in Afghanistan as population is increased. These findings will bring better possibilities for breeders to easily choose the elite varieties for the rice production purposes and increase the production.

\section{Conflict of interest}

The authors declare no conflict of interests. 


\section{Acknowledgement}

The authors are grateful the Japan International Cooperation Agency (JICA) for providing a scholarship to Ramin Rayee.

\section{Reference}

[1] C. Wei et al., Protein profiles of major Korean rice cultivars, Preventive Nutritional Food Science. 12(2) (2007) 103-110.

[2] T. D. Xuan, et al,. Allelopathic momilactones A and B are implied in rice drought and salinity tolerance, not weed resistance, Agronomy for Sustainable Development. 36(3) (2016) 1-5.

[3] Z. Noori, Physicochemical properties and morphological observations of selected local rice varieties in northern Afghanistan, International Journal of Agriculture, Environment and Food Sciences. 2 (2018) 99-103.

[4] V. Thomas, A. M., Ramzi, SRI contributions to rice production dealing with water management constraints in northeastern Afghanistan, Paddy and Water Environment. 9(1) (2011) 101-109.

[5] International Center for Agricultural Research in the Dry Areas (ICARDA).. ANNUAL REPORT 2014 International Center for Agricultural Research in the Dry Areas, (2015).

[6] FAO, Food and agricultural organization of the United Nations Rice Market Monitor, (2017). Available: www.fao.org/economic/RMM.

[7] E. S. Gong et al., Phytochemical profiles and antioxidant activity of brown rice varieties, Food chemistry. 227 (2017) 432-443.

[8] K.K. Adom, R.H. Liu, Antioxidant activity of grains, Journal of Agricultural and Food Chemistry. 50(21) (2002) 6182-6187.

[9] M.Walter et al., Antioxidant properties of rice grains with light brown, red and black pericarp colors and the effect of processing, Food Research International. 50(2) (2013) 698-703.

[10] S. Yodmanee, T.T. Karrila, P.Pakdeechanuan, Physical, chemical and antioxidant properties of pigmented rice grown in Southern Thailand, International Food Research Journal. 18(3) (2011) 901-906.

[11] J.Ø. Moskaug et al., Polyphenols and glutathione synthesis regulation, Am. J. Clin. Nutr. 81(2) (2005) 277-283.

[12] F. D. Goffman, C. J. Bergman, Rice kernel phenolic content and its relationship with antiradical efficiency, Journal of the Science of Food and Agriculture. 84(10) (2004) 1235-1240.

[13] Y. Shao et al., Identification and quantification of phenolic acids and anthocyanins as antioxidants in bran, embryo and endosperm of white, red and black rice kernels (Oryza sativa L.), Journal of Cereal Science. 59(2) (2014) 211-218.

[14] A.A. Elzaawely, T.D. Xuan, S. Tawata, Essential oils, kava pyrones and phenolic compounds from leaves and rhizomes of Alpinia zerumbet (Pers.) B.L. Burtt. \& R.M. Sm. and their antioxidant activity, Food Chemistry. 103(2) (2007) 486-494.

[15] R. Singh, N. Kumari, Comparative determination of phytochemicals and antioxidant activity from leaf and fruit of Sapindus mukorrossi Gaertn. - A valuable medicinal tree, Industrial Crops and Products. 73 (2015) 1-8.

[16] N.S. Rani et al., Historical significance, grain quality features and precision breeding for improvement of export quality basmati varieties in India, Indian Journal of Crop Science. 1(12) (2006) 29-41. 
[17] Q. Jing et al., Adaptation and performance of rice genotypes in tropical and subtropical environments, NJAS - Wageningen Journal of Life Sciences. 57(2) (2010) 149-157.

[18] T. Tsukaguchi, S. Nitta, Y. Matsuno. Cultivar differences in the grain protein accumulation ability in rice (Oryza sativa L.), Field Crops Research. 192 (2016) 110-117.

[19] J.D. Abacar et al., Variation in yield and physiochemcial quality traits among mutant of Japonica rice cultivar Wuyujing 3, Rice Science. 23(1) (2016) 22-41.

[20] K.R. Bhattacharya, Rice Quality: A guide to rice properties and analysis, New Delhi, 2011, pp. 461-474.

[21] A.K. Dutta et al., Antioxidant properties of ten high yielding rice varieties of Bangladesh, Asian Pacific Journal of Tropical Biomedicine. 2(1) (2012) 99-103.

[22] Q.A. Panhwar et al., Quality and antioxidant activity of rice grown on alluvial soil amended with $\mathrm{Zn}, \mathrm{Cu}$ and Mo, South African Journal of Botany. 98 (2015) 77-83.

[23] Y. Shao et al., Analysis of genotype, environment, and their interaction effects on the phytochemicals and antioxidant capacities of red rice (Oryza sativa L.), Cereal Chemistry. 92(2) (2015) 204-210. 